\title{
HORMONAL CONTROL OF GUT MOTILITY IN RUMINANTS AND NON-RUMINANTS AND ITS NUTRITIONAL IMPLICATIONS
}

\author{
J. FIORAMONTI AND'L. BUENO
}

Department of Pharmacology, INRA, 180 chemin de Tournefeuille, 31300 Toulouse, France

\section{CONTENTS}

INTRODUCTION.

BASIC PATTERNS OF DIGESTIVE MOTILITY AND PROPULSION $\quad \cdot 170$

MOTOR PATTERNS . . . . . . . . . . . . . . . 170

Stomach . . . . . . . . . . . . . . . . 170

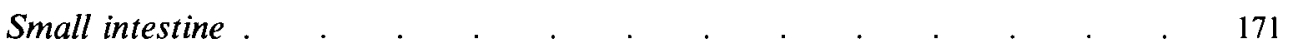

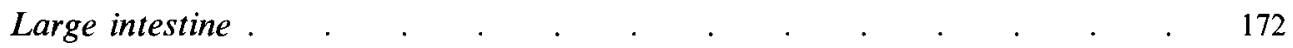

RELATIONSHIPS BETWEEN MOTILITY AND FLOW OF DIGESTA . . . 173

Stomach . . . . . . . . . . . . . . . . . . 173

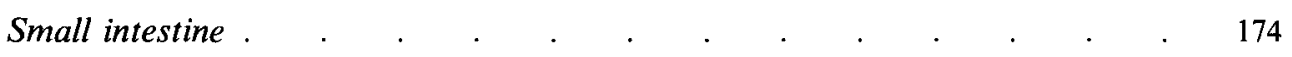

Large intestine . . . . . . . . . . . . . . . . . 174

HORMONES AND DIGESTIVE MOTILITY . . . . . . . . . . 174

BLOOD HORMONE FLUCTUATIONS AND GASTROINTESTINAL MOTOR
CYCLES

HORMONAL CONTROL OF THE POSTPRANDIAL PATTERN . . . . . 177

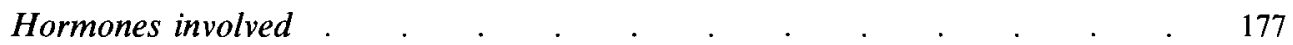

Central v. peripheral site of action . . . . . . . . . . . . .

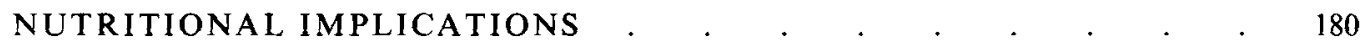

HORMONAL INVOLVEMENT IN THE CONTROL OF DIGESTIVE MOTILITY
BY FOOD
H

CONSEQUENCES OF THE HORMONAL CONTROL OF DIGESTIVE MOTILITY
ON NUTRIENT ABSORPTION

CONCLUSIONS

REFERENCES . . . . . . . . . . . . . . . . . . . $\quad . \quad . \quad 183$

\section{INTRODUCTION}

The function of gastrointestinal (GI) motility is to mix and propel food or digesta and to aid the absorption of nutrients. In all animals digestive processes are influenced by feeding behaviour, which in simple-stomached species such as the dog and pig, as well as in man, this disrupts the endogenous cyclic pattern of GI motility (Code \& Marlett, 1975; Ruckebusch \& Bueno, 1976; Vantrappen et al. 1977). Although in ruminants the abomasum has similar digestive functions to the stomach of simple-stomach animals (Ash, 1961), their slow ingestion of food over long periods and the high capacity of storage of 
their forestomachs leads to a continuous secretion of gastric juice and a steady outflow of digesta to the duodenum (Kay, 1965; McLeay \& Titchen, 1975). These gastric peculiarities of the ruminant are associated with a cyclic pattern of intestinal motility independent of feeding behaviour.

The patterns of digestive motility are known to be under a neurohormonal control at different levels from the alimentary tract wall to the central nervous system. There are at least two circumstances when a hormone can be thought to play a role in the regulation of the motor pattern: (1) when fluctuations of circulating levels of a hormone occur concurrently with variations in the rhythms of the motility events, (2) when modifications of the motor rhythm are induced by exogenous administration of these hormones in a physiological range. Consequently this review will present: first a description of the basic motor patterns, their postprandial modifications and their role in the propulsion of the digesta; second the present knowledge on the role of blood hormone fluctuations and the action of exogenous hormone administration on the fasting and the postprandial motor patterns with particular attention to the balance between peripheral and central mechanisms, and finally the nutritional implications on the basis of the known effects of nutrients on both GI motility and hormonal secretions.

\section{BASIC PATTERNS OF DIGESTIVE MOTILITY AND PROPULSION}

\section{Stomach}

$$
\text { MOTOR PATTERNS }
$$

Records of antral motility during the fasting or interdigestive period in a non-ruminant species such as the dog (Itoh et al. 1977), as well as independently of the feeding behaviour in a ruminant species such as the sheep (Ruckebusch \& Bueno, $1977 \mathrm{a}$ ), show a basic pattern of high-amplitude contractions grouped in phases lasting 20-90 min, separated by a period of quiescence, and appearing at 90-120 min intervals.

In ruminants, recordings of fundic myoelectrical activity showed the presence of electrical events (Ruckebusch, 1970), but the occurrence of active fundic contractions and their physiological role remains uncertain. However, in the calf, a pre-ruminant with a digestive physiology close to non-ruminant and simple-stomached species, it is well established that the motility of the fundus participates in abomasal function. Great changes in its pattern occur during and after suckling; an extrinsic inhibitory response controlled by the vagus during suckling is followed by an increase in total activity in the first $2 \mathrm{~h}$ postprandial period (Bell \& Grivel, 1975). In adult sheep or cattle, the abomasal inflow of digesta is related more to reticulo-omasal motility and the mean pressure of the abomasum than to fundic motility (Kay, 1965). However, in adult cows irregular contractions in the fundus may be uncoordinated with omasal and antral contractions (Svendsen, 1969). Mechanical contractions of the antrum occur rhythmically at a frequency of five or six per min in sequences of three to six waves at $10-30 \mathrm{~s}$ intervals. The contractions are propagated towards the pylorus, which opens and shuts in continuation of these peristaltic waves (Ehrlein, 1970). Such activity appears continuously for 90-120 $\mathrm{min}$ and is followed by a period of quiescence of about $10 \mathrm{~min}$ in sheep on a hay regimen. Fasting for $24 \mathrm{~h}$ leads to a slight lengthening of the period of quiescence, whilst overfeeding induced by palatable concentrates increases the duration of antral motor activity (Bueno, 1977).

The fundamental characteristic of fundic motility is the presence of a steady resting potential of the smooth muscle cells with no regular fluctuations (slow waves) at least in dog and man (Kelly et al. 1969; Hinder \& Kelly, 1977). The other important property of the proximal stomach is the receptive relaxation, mediated by inhibitory neurons in vagal 
nerves (Abrahamsson, 1973), which enables it to receive readily boluses of food from the oesophagus. The patterns of contractile activity of the canine gastric corpus and antrum have been described in detail by Itoh et al. (1977) and by Gill et al. (1985). The interdigestive pattern consists of series of high-amplitude contractions for 15-25 min followed by a long lasting $(70-110 \mathrm{~min})$ motor quiescence. By analogy with the nomenclature used for the small intestine (see below) this pattern has been divided in three successive periods: phase 1 quiescence, phase 2 moderate activity, phase 3 maximal activity. The contractions of the corpus and the antrum are coordinated; a slow contraction of the corpus lasting about $30 \mathrm{~s}$ is associated with three to five more rapid contractions of the antrum (Gill et al. 1985). After a meal, the digestive pattern is characterized by steady lowamplitude contractions (four to five per $\mathrm{min}$ ) in the gastric antrum with no significant motor activity in the gastric body. An intermediate pattern characterized by contractions of the body and higher-amplitude contractions of the antrum, together with the steady postprandial contractions, is present for a variable period before the gastric motility returns to a typical fasted state (Itoh et al. 1977).

However, as far as we know, such a pattern of gastric motility has been found only in the dog (Itoh et al. 1977), the pig (Plonait, 1974) and in man (Rees et al. 1982). In the rat (Bueno et al. 1982a) and the rabbit (Deloof \& Rousseau, 1985) there is no cyclic organization of the gastric motility, and feeding induces an increase of both amplitude and frequency of the contractions.

\section{Small intestine}

The basic motor pattern of all animal species investigated, except the cat (Roche et al. 1982), consists of migrating motor (or myoelectric depending on the variable measured) complexes (MMC), first identified by Szurszewski (1969) as 'a caudad band of largeamplitude action potentials starting in the duodenum and traversing the small bowel'. Each MMC corresponds to three consecutive phases: phase 1 has little or no contractile activity (quiescent phase), phase 2 has intermittent and irregular contractions, while the contractions of phase 3 occur at their maximal rate, which is determined by the frequency of the slow waves. The duration of phase 3 activity is relatively constant, but that of other phases varies from cycle to cycle, depending on the flow of digesta (Ruckebusch \& Bueno, $1977 \mathrm{~b}$ ). According to the animal species, the duration of the MMC cycle varies between 60 and $120 \mathrm{~min}$ (Bueno \& Ruckebusch, 1978), except in rats in which MMC occurs at 15-20 min intervals (Ruckebusch \& Fioramonti, 1975). Sometimes it appears that phase 3 activity of an MMC is initiated at sites distal to the duodenum. Also it is not uncommon for an MMC to disappear after being propagated along about two-thirds of the small bowel.

In ruminants the character of the small intestine motor pattern is, as for the abomasum, the omnipresence of the cyclic activity independent of feeding behaviour (Bueno \& Ruckebusch, 1978), although variations occur in the phase 2 duration according to the nature and the amount of food eaten (Bueno \& Ruckebusch, 1978). However, in preruminant animals such as calves, feeding large amounts of milk disrupts the intestinal cyclic activity by increasing the duration of phase 2 and extending the interval between the two consecutive postprandial MMC (Ruckebusch \& Bueno, 1973; Sissons, 1983).

In non-ruminants, feeding is accompanied by a disruption of this $\mathrm{MMC}$ to give a 'postprandial' pattern characterized by the irregular occurrence of small-amplitude contractions similar to those observed during phase 2 of the MMC (Bueno et al. 1975; Code \& Marlett, 1975). The difference between ruminants and non-ruminants in this respect is exemplified in Fig. 1.

This disruption of the MMC pattern and its replacement by a 'fed' pattern is related to 

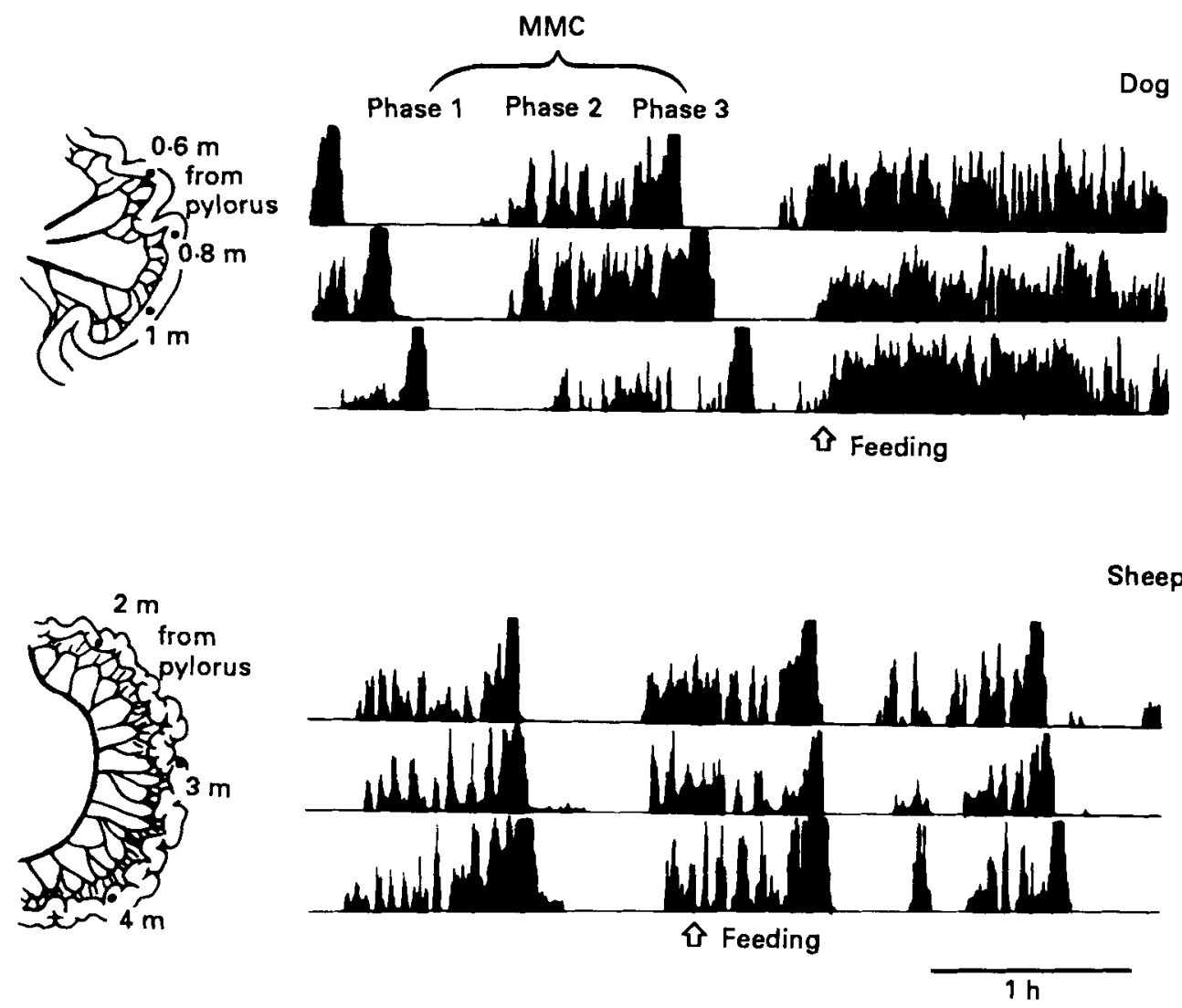

Fig. 1. Integrated records of myoelectric spiking activity of the jejunum in a dog and a sheep. After feeding, migrating myoelectric complexes (MMC) were disrupted in the dog and remained unchanged in the sheep (from Bueno et al. 1975).

multiple factors, including the energy content of the meal, the nature of nutrients and the frequency of meals, and is mediated through mixed neural and humoral factors. In dogs, it has been established that there is a linear relationship between the duration of the postprandial state of gut motility and the energy content of a meal (De Wever et al. 1978). However, non-nutrient factors are also involved in the postprandial disruption of the MMC pattern, since sham-feeding significantly delays the next phase 3 in man (Defilippi \& Valenzuela, 1981). On the other hand, meal frequency modulates the effects of feeding on small intestinal motility. For example, in pigs (Ruckebusch \& Bueno, 1976) or in rats (Ruckebusch \& Ferre, 1973), ingestion of a daily large meal disrupts the MMC for several hours, while under ad lib conditions the MMC frequency is similar to that observed in the fasted state in pigs and is only reduced in rats during the night, which corresponds to a period of intense ingestion. However, in adult as well as in neonatal pigs, feeding a standard meal only induces a $1 \mathrm{~h}$ delay in the onset of the next phase 3 (Burrows et al. 1986; Rayner \& Wenham, 1986).

\section{Large intestine}

A universal pattern analogous to that observed for the small intestine has not been found for the large bowel. A common feature of the colon in all mammalian species investigated 
is a duality of the contractile activity: tonic contractions corresponding to myoelectrical events characterized by short spike bursts and phasic contractions corresponding to long spike bursts. However, the spatial and temporal organization of these two kinds of contractions which form the colonic motor pattern is peculiar in each mammalian species investigated. This pattern is independent of colonic anatomy and of the traditional regimen of the animal species, but gross similarities exist within species producing moulded faeces such as the pig, the dog or man, and within species that form faeces in pellets such as the rabbit or the sheep (Fioramonti, 1981).

Ruminants, at least sheep and cows, are characterized by a peculiar coordination of the ileal and caeco-colonic activity (Fioramonti \& Ruckebusch, $1978 a$; Fioramonti \& Hubert, 1980): when a phase 3 of an MMC migrates on the terminal ileum intense contractions transfer the caecal content to the proximal colon. However, motor patterns of the spiral colon are very different in the sheep and the cow. In sheep, a very-high tonic activity associated with rapid peristaltic contractions are responsible for the pellet formation, while in cows a series of powerful contractions migrates slowly along the spiral and terminal colon and leads to defaecation.

In non-ruminant species, colonic motility has been mainly investigated in dogs and in man. In dogs high-amplitude colonic contractions are grouped in phases lasting 4-6 min and appearing at a rate of two to three per $h$ in the fasted state with an increase in frequency (four or five per h) during the $10 \mathrm{~h}$ after a daily meal (Fioramonti \& Bueno, 1983). In man the most typical characteristic of colonic motility, not seen in animals, consists of a very low activity during the night time (Frexinos et al. 1985). After a $3000-4000 \mathrm{~kJ}$ meal the frequency of colonic contractions is increased for 2-3 h. Such an increase in colonic motility after a meal seems to be a common feature of non-ruminants, but is limited to the caecum in some species such as the rabbit or the rat.

\section{RELATIONSHIPS BETWEEN MOTILITY AND FLOW OF DIGESTA Stomach}

In terms of transit of digesta the three major functions of the stomach are the receipt of food, the storage of ingested food and the emptying of liquids and solids.

In ruminants no adaptative relaxation of the proximal abomasum has been described, and its filling is intermittent as small gushes enter at about 1 min intervals when the omasoabomasal orifice opens in coordination with contractions of the reticulo-rumen (Bueno \& Ruckebusch, 1974). In ruminants, a peculiar role is played by the duodenal bulb in the control of gastric emptying. Radioscopic studies performed in sheep have shown that the passage of gastric contents through the pylorus is not immediately followed by a duodenal propulsive wave (Quigley \& Louckes, 1962) and distension of the duodenal bulb is required to induce contractions propagated towards the duodenum (Wenham, 1974). However, gastric emptying in ruminants is nearly continuous, except during the phases of quiescence of the abomasum associated with the onset of phase 3 activity in the duodenum, where no flow passes the pylorus.

In non-ruminants given discrete meals, the entry of a large amount of food into the stomach leads to adaptive (or receptive) relaxation of the muscle wall and permits the fundus and the upper body to act as a reservoir (Jahnberg, 1977). The rhythmic contractions of the distal stomach are thought to control the trituration and emptying of solids, whereas the tonic contractions of the proximal stomach govern the rate of emptying of liquids. The function of the pylorus has not been clearly defined. Some feel that its function is to prevent duodeno-gastric reflux, whereas others have shown that the pylorus is a true sphincter that may control the emptying of food from the stomach (Fisher \& 
Cohen, 1973). However, more recent studies suggest that both the pylorus and the antrum can control the gastric emptying of both liquids and digestible solids (Hinder, 1983).

\section{Small intestine}

Using an electromagnetic flow-meter to measure digesta flow continuously and electromyography to record intestinal motility, it has been observed in sheep that the majority of intestinal contents flowed intermittently for periods of 10-15 min at the same frequency as the migrating myoelectric complex. Two-thirds of this flow occurred in the 4-6 min immediately preceding the periods of phase 3 activity and consequently the mean velocity of digesta was identical to that of phase 3 migration (Bueno et al. 1975).

In non-ruminants the greatest flow of digesta occurs generally during the postprandial disruption of the MMC pattern. However, the role of $\mathrm{MMC}$ in the propulsion of digesta is not negligible since gastric emptying is not terminated when the MMC reappear on the jejunum (Banta et al. 1979) and since MMC are not disrupted in several feeding conditions (see p. 172). In the latter case, flow of digesta is also intermittent and associated with MMC (Rayner \& Wenham, 1986) but the close relationship between the propagation of MMC and the velocity of transit described in ruminants has not been found in simplestomach species (Bueno et al. 1975). Moreover the propulsive role of each phase of the MMC still remains controversial depending on the experimental model. The maximal transit rate of a marker has been found associated with phase 3 using a jejunal isolated loop (Sarr et al. 1980) or with phase 2 when experiments were performed on an intact intestine in the same species, the dog (Bueno et al. 1975).

\section{Large intestine}

The two kinds of colonic contractile activity have opposite effects on the propulsion of digesta. Phasic contractions ensure the mixing and the aboral progression of colonic contents while the tonic activity acts as a brake.

In ruminants producing hard pellets, such as sheep, the spiral colon is characterized by a permanent and intense tonic activity associated with a mean colonic transit time of $20 \mathrm{~h}$, while in cows the tonic activity of the spiral colon is very low and the colonic transit time does not exceed $10 \mathrm{~h}$ (Hecker \& Grovum, 1975; Fioramonti \& Hubert, 1980).

Several studies in non-ruminant species have confirmed the propulsive and brake function of colonic motility. In dogs the spontaneous fluctuations of the phasic activity are positively correlated with the spontaneous changes in the velocity of transit of a marker introduced in the proximal colon (Fioramonti et al. 1980). Similarly in pigs, a low-residue diet induced a 3-fold increase in colonic mean retention time which was related to a decrease in phasic activity and an increase in tonic activity (Fioramonti \& Bueno, 1980).

However, in humans, despite the many studies of colonic motility or colonic transit time, relations between muscle activities and digesta movement have not been confirmed.

\section{HORMONES AND DIGESTIVE MOTILITY}

According to Grossman (1977) there are at least two criteria necessary for a candidate hormone to play a physiological role in the regulation of GI motility: (1) demonstration of relations between spontaneous cyclic motor events and plasma levels and (2) the induction of motor events associated with the highest blood levels when infused at physiological doses. These two criteria have been demonstrated for most of the GI tract, but only the effects of hormone infusions have been investigated on colonic motility. 


\section{BLOOD HORMONE FLUCTUATIONS AND GASTROINTESTINAL}

\section{MOTOR CYCLES}

Studies in non-ruminants, mainly in dogs and humans indicate a possible role for motilin, pancreatic polypeptide and somatostatin in mechanisms regulating gastric and gut motility. Cyclical variations of blood motilin levels associated with the duodenal occurrence of MMC were described first in dogs (Chey et al. 1978; Itoh et al. 1978; Keane et al. 1980; Lee et al. 1980). These cyclical variations of motilin concentration in blood were also detected in man (Vantrappen et al. 1979; Peeters et al. 1980). However, in humans the peak of motilin preceded (10-15 min) the appearance of maximal motor activity on the stomach while they were concomitant in dogs, although, in man, intense periods of gastric motility have been recorded in the absence of cyclical variations of motilin in blood (Rees et al. 1982).

Motilin was first isolated from the duodenum of pigs (Brown et al. 1972) but experiments performed in this species showed no fluctuation of blood motilin with the phases of MMC (Borody et al. 1981). However further experiments performed with a more-prolonged fast, $17 \mathrm{~h} \mathrm{v.} 4-5 \mathrm{~h}$ in the first study, indicated a correlation between fluctuations in levels of blood motilin and the initiation of MMC at the antro-duodenal junction (Rayner $e t$ al. 1987).

Studies of motilin in the control of MMC frequency have not provided consistent evidence for this hormone having a physiological role in GI motor function. Itoh et al. (1975) showed in dogs that intravenous administration of porcine motilin induced the premature formation and development of phase 3 activity propagated from the stomach to the small intestine, similar to the spontaneous activity. However, a prolonged infusion at physiological dose maintaining a high plasma level was not accompanied by the premature induction of new MMC (Bueno et al. 1982 b). Furthermore, in pigs, porcine as well as synthetic 13-Norleu motilin were unable to induce premature gastric or duodenal phase 3 activity (Bueno et al. 1982 b).

It seems, however, that the regulatory role of motilin on the MMC may be restricted to the gastroduodenal area, since in man no peak of blood motilin could be demonstrated for the phase 3 activity originated in the small intestine while gastric MMC were associated with motilin fluctuations in the same subjects (Bormans et al. 1987). Also, intravenous infusion of pancreatic polypeptide suppressed both plasma motilin peaks and gastric MMC in man, and the concomitant infusion of motilin restored the gastric motor pattern (Janssens et al. 1983).

Several experiments have been performed in dogs to elucidate the nature of the mechanisms involved in the action of motilin on smooth muscles. Intrinsic and motilininduced gastric MMC are inhibited by atropine and hexamethonium (Ormsbee et al. 1979) suggesting that the action of motilin is mediated by nervous pathways. In contrast, in vitro analysis showed (Domschke et al. 1976) that the stimulatory effect of motilin on the GI muscle is not mediated via nervous pathways but through a direct action on the muscle cell, with tetrodotoxin or atropine being unable to modify the response to motilin. Vagal cooling selectively abolished gastric cyclic MMC and plasma motilin variations (Hall et al. 1984), suggesting that the vagus controls the gastric MMC through a release of motilin. Moreover, exogenous motilin is still able to induce a gastric MMC during vagal cooling. Similarly in man atropine infusion abolishes both motilin peaks and gastric MMC (You et al. 1980). On the other hand, a denervated autotransplanted gastric pouch still showed spontaneous phase 3 activity in accord with similar activity in the main stomach (Thomas et al. 1979). In another study continuous gastric contractions were observed on a denervated gastric pouch during a long-lasting intravenous motilin infusion, whilst at the 
same time only phase 3 activity was seen in the main stomach (Nakaya et al. 1981). Thus both myogenic and neurogenic components seem to be involved in the motilin regulation of the MMC profile.

The factors involved in the duodenal release of motilin are not clearly understood. In dogs, duodenal alkalinization is able to induce a motilin peak associated with phase 3 activity (Lee et al. 1978; Fox et al. 1981). This effect is in contrast to a study of duodenal acidification in man which induced a release of motilin, initiation of duodenal MMC and inhibition of stomach motility (Lewis et al. 1979). Some drugs such as morphine which initiate premature intestinal phase 3 motor activity, also induce a motilin peak. However, under these conditions Sarna et al. (1983) reported that the hormone was released after development of phase 3 activity.

Somatostatin exhibits great plasma fluctuation at the same rhythm as that of MMC with a high peak occurring at the time of duodenal phase 3 activity in dogs (Aizawa et al. 1981) as well as in men (Peeters et al. 1982). A physiological role of somatostatin has been confirmed at the intestinal level by intravenous infusion which increases the MMC frequency in dogs (Ormsbee et al. 1978; Poitras et al. 1980; Bueno et al. 1982 b) as well as in man (Lux et al. 1980; Peeters et al. 1983). However, somatostatin has been found to inhibit the occurrence of MMC in pigs (Bueno et al. 1982 b).

There is also increasing evidence that the gastroduodenal and jejuno-ileal motor pattern are not governed by the same hormones. Intravenous infusion of somatostatin was reported to reduce motilin concentration in blood (Poitras et al. 1980; Peeters et al. 1983), inhibit the occurrence of gastro-duodenal MMC, and increase the rate of jejunal MMC. In contrast a peak of plasma somatostatin accompanying the duodenal development of phase 3 activity was observed during motilin infusion (Peeters et al. 1982). Furthermore, it appears that MMC initiated on the duodenum are not associated with motilin peaks (Bormans et al. 1987), suggesting that somatostatin rather than motilin controls the initiation and propagation of intestinal MMC. This hypothesis is re-inforced by observations showing that local infusion of somatostatin through a mesenteric artery increased the frequency of MMC at the site of infusion and aborally (Hostein et al. 1984) and induces ectopic phase 3 activity even in the fed state (Schippers et al. 1986). Moreover, in patients with a somatostatinoma the number of periods of intestinal phase 3 activity was found to be increased (Krejs et al. 1979). Like motilin, some drugs seem to induce jejunal phase 3 activity through a release of somatostatin. For example, $\beta$-adrenergic agonists, such as isoproterenol, induce such activity during the postprandial state (Yanda \& Summers, 1983) as does somatostatin infusion. This is associated with hypersomatostatinaemia without a significant change in the blood motilin level (Summers et al. 1984).

Pancreatic polypeptide exhibits cyclic plasma increases associated with those of motilin in both man (Janssens et al. 1982) and dogs (Keane et al. 1980). These variations in pancreatic-polypeptide concentration have been linked to phase 3 activity in the stomach as well as to the level of gastric acid secretion (Schwartz et al. 1979). However, in man pancreaticobiliary secretion, pancreatic-polypeptide release and intestinal motor activity during the interdigestive period may be causally related (Owyang et al. 1983). Intravenous infusion of pancreatic polypeptide increases the frequency of jejunal MMC in both dogs and pigs (Bueno et al. 1982 b). But, in man, pancreatic-polypeptide infusion does not modify the intestinal MMC rhythm (Janssens et al. 1982), although the hormone was found to induce an inhibition of the gastric motor cycles associated with a decrease in blood motilin (Janssens et al. 1983).

Cyclical variations of gastrin concentration in blood associated with phase 2 activity of the proximal duodenum have been observed in both dogs (Hall et al. 1983) and humans 
(Peeters et al. 1980). Despite these cyclical blood variations gastrin cannot be considered as a hormone regulating the MMC profile since its intravenous infusion disrupts the fasting pattern of motility (Marik \& Code, 1975).

\section{HORMONAL CONTROL OF THE POSTPRANDIAL PATTERN}

A hormone may be considered as responsible for the change from the fasted to the fed motor pattern if its release occurs after a meal and if its infusion, at physiological doses, in fasted subjects induces a motor pattern typical of the fed state. Summaries of studies showing some effects of infused hormones on motor or myoelectric patterns in different species are represented in Tables 1 and 2.

\section{Hormones involved}

Among the hormones released by a meal, gastrin (Weisbrodt et al. 1974; Marik \& Code, 1975; Wingate et al. 1978a), insulin (Bueno \& Ruckebusch, 1976), cholecystokinin (CCK) (Mukhopadhyay et al. 1977; Wingate et al. 1978a), secretin, glucagon (Wingate et al. $1978 \mathrm{~b}$ ), and neurotensin (Al Saffar \& Rosell, 1981; Thor et al. 1982) alter the cycling pattern of the MMC when infused intravenously. This suggests that these substances may play a role in the change of the motility pattern after feeding. However, it is unlikely that a single hormone is responsible for the postprandial change of the GI motor pattern since for each hormone there are arguments against a physiological motor action. For example, in dogs a long-lasting disruption of MMC occurs after fat ingestion, but with no significant increase in plasma gastrin and insulin (Eeckhout et al. 1978). Indeed significant increases in gastrin and insulin concentrations in blood induced by glucose ingestion or intravenous infusion are not associated with a disruptive of the MMC pattern (Eeckhout et al. 1978). Similarly the disruption effect on MMC of insulin infusion is abolished in pigs when a normal blood glucose level is maintained by a concomitant glucose infusion (Rayner et al. 1981). On the other hand, infusions of CCK or gastrin, or both, disrupt the duodenal MMC in dogs, but the cyclic peaks of motilin concentrations in blood persist while in the same animals plasma motilin is reduced after a meal (Lee et al. 1980). Moreover, analysis of intestinal myoelectric activity in dogs indicates that the pattern of contractions induced by $\mathrm{CCK}$, secretin or gastrin infusion is different from that observed after a meal (Wingate et al. $1978 a$ ).

In rats as well as in humans neurotensin infusion induces a pattern of intestinal contractions very similar to that observed after feeding (Al Saffar \& Rosell, 1981; Thor et al. 1982). However, in man the plasma concentration of neurotensin induced by an infusion able to disrupt the MMC pattern is very far from the plasma concentration observed after a meal (Shaw \& Buchanan, 1983). In rats intestinal neurotensin exhibits circadian variations, with a maximum during the night time which corresponds to a period of intense ingestive behaviour associated with a disruption of MMC (Ferris et al. 1986).

Regulation by hormones of the postprandial pattern of GI motility is a very attractive hypothesis and hormones are undoubtly involved in the disruption of the MMC, at least in the stomach, since feeding abolishes the $\mathrm{MMC}$ in an autotransplanted fundic pouch (Thomas \& Kelly, 1979). However, nervous factors are also of importance since vagotomy delays the onset of the fed pattern (Ruckebusch \& Bueno, 1977b) and the MMC occurring in an autotransplanted segment of dog jejunum are not disrupted by feeding (Sarr \& Kelly, 1981).

The motility of the colon is stimulated after feeding. Intravenous infusion of postprandially-released hormones such as gastrin (Snape et al. 1978), CCK (Renny et al. 1983) or neurotensin (Thor \& Rosell, 1986) stimulate colonic motility. However, no 
Table 1. Comparative effects of the systemic infusion of gastrointestinal hormones on cyclical variations in the fasted state in ruminant and non-ruminant species

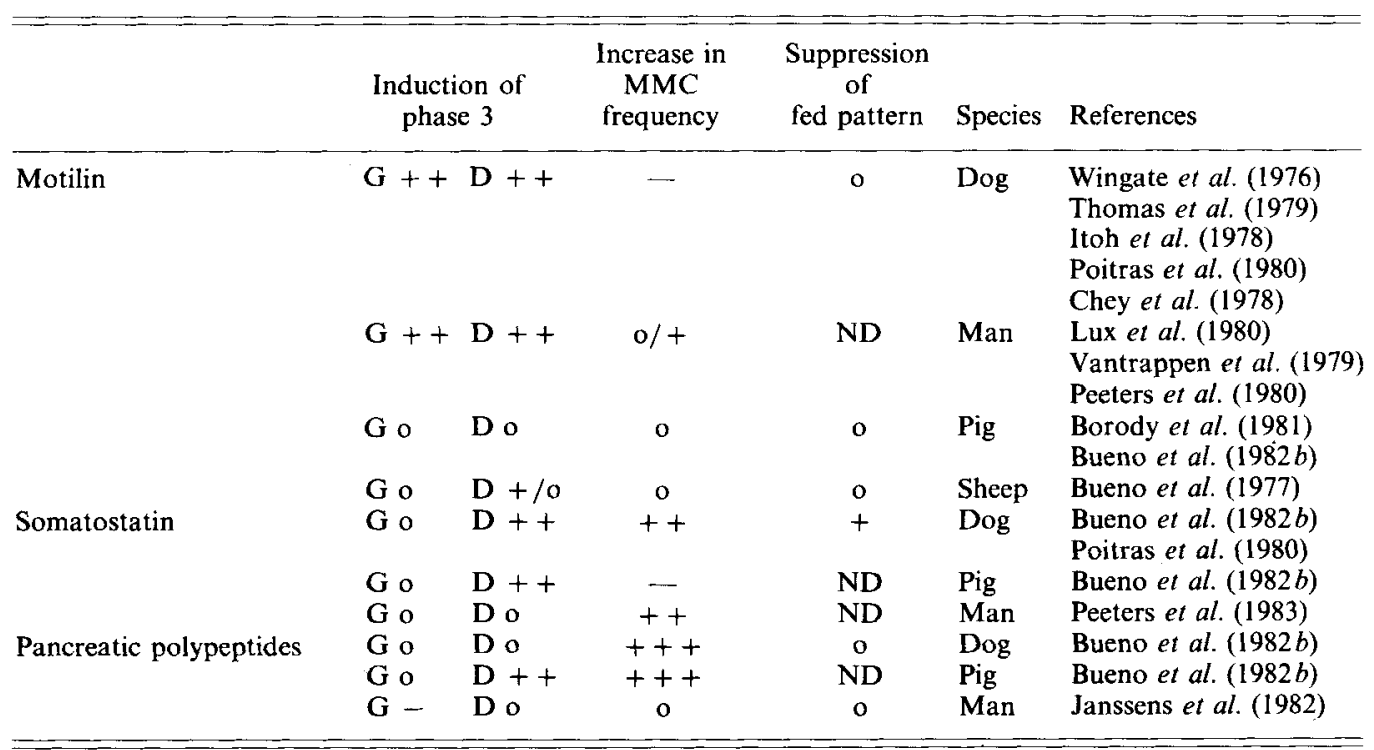

+ , increase; o, no effect; -, decrease; G, gastric; D, duodenal; ND, not determined;

Table 2. Comparative effects of systemic infusion of gastrointestinal (GI) and pancreatic hormones released after feeding on the GI motor pattern in ruminant and non ruminant species

\begin{tabular}{|c|c|c|c|c|c|}
\hline & $\begin{array}{c}\text { Disruption } \\
\text { of } \\
\text { MMC } \\
\text { pattern }\end{array}$ & $\begin{array}{l}\text { Initiation of } \\
\text { fed pattern }\end{array}$ & $\begin{array}{c}\text { Duration } \\
\text { of } \\
\text { fed pattern }\end{array}$ & Species & References \\
\hline \multicolumn{6}{|l|}{ Pancreatic hormones } \\
\hline Insulin & +++ & ++ & ++ & $\begin{array}{l}\text { Dog, sheep } \\
\text { Rat }\end{array}$ & $\begin{array}{l}\text { Bueno et al. (1977) } \\
\text { Pascaud et al. (1982) }\end{array}$ \\
\hline Pancreatic polypeptide & o & o & - & Dog, pig & Bueno et al. $(1982 b)$ \\
\hline & + & + & o & Man & Peeters et al. (1983) \\
\hline Somatostatin & $+(\mathrm{GD})$ & o & 0 & Dog, pig & $\begin{array}{l}\text { Poitras et al. }(1980) \\
\text { Bueno et al. }(1982 b)\end{array}$ \\
\hline & & & & Man & Peeters et al. (1983) \\
\hline \multicolumn{6}{|l|}{ GI hormones } \\
\hline Motilin & o & & & Dog & $\begin{array}{l}\text { Itoh et al. (1975) } \\
\text { Wingate et al. }(1976)\end{array}$ \\
\hline & & & & Man & Rees et al. (1982) \\
\hline Gastrin & ++ & + & $\circ$ & Dog & $\begin{array}{l}\text { Eeckhout et al. (1978) } \\
\text { Marik \& Code (1975) } \\
\text { Schippers et al. (1986) }\end{array}$ \\
\hline & & & & Cow & Ruckebusch (1971) \\
\hline $\mathrm{CCK}_{33}, \mathrm{CCK}_{2}$ & ++ & $\dot{t}+$ & ++ & Dog & Weisbrodt et al. (1976) \\
\hline & & & & Rat & Bueno \& Ferre (1982) \\
\hline & & & & Sheep & Bueno \& Fioramonti (1980) \\
\hline Neurotensin & ++ & ++ & $+1-$ & Rat & Al Saffar \& Rosell (1981) \\
\hline
\end{tabular}

+ , increase; o, no effect; - , decrease; GD, gastroduodenal; CCK, cholecystokinin. 
information is available to confirm a physiological role for these hormones in the control of colonic motor response to eating for which a neural mechanism (Snape et al. 1979) associated with the entering of digesta into the colon (Fioramonti \& Bueno, 1983) seems of importance.

\section{Central v. peripheral site of action}

Numerous findings indicate a link between the brain and the digestive tract in both physiological and pathological states. Smith et al. (1977) showed that a hormone, the thyrotropin-releasing hormone, administered into a lateral ventricle of the brain (intracerebroventricular (icv) administration) stimulated colonic motility in anaesthetized rabbits. The central effects of hormones on digestive motility were confirmed 5 years later by Bueno \& Ferre (1982). These workers showed that central administration of somatostatin at a picomolar dose (inactive by the systemic route) increased the frequency of jejunal MMC in the rat while, in contrast, icv administered CCK disrupted the MMC pattern. Since then increasing evidence that several hormones and other neuropeptides may affect the pattern of GI motility when centrally administered has accumulated. These peptides may be divided into two groups according to the digestive state and the corresponding motor profile considered.

The first group includes hormones which disrupt the MMC pattern after central administration. Among them CCK seems to play an important role. After feeding, CCKlike immunoreactivity has been found to increase in the primate hypothalamus (Schick et al. 1987). Administration (icv) of CCK disrupted the jejunal MMC and induced a fed pattern in both rats (Bueno \& Ferre, 1982) and dogs (Karmeli et al. 1987). More recently, central administration after a meal of antiserum against CCK or the CCK-receptor antagonist asperlicin was found to restore a MMC pattern in rats (Duc, 1988). These results are in favour of a physiological role of CCK at the central level in the postprandial disruption of the MMC pattern, however, they probably concern neuronal CCK which cannot be considered as a hormone.

At the peripheral level the postprandial role of CCK in the control of the GI motor pattern may be neuronal since $\mathrm{CCK}_{8}$ immunoreactivity has been demonstrated in axons and nerve cell bodies of the enteric nervous system (Larsson \& Rehfeld, 1979). Moreover, one of the main mechanisms involved in the effects of CCK is an indirect action resulting in an increase in acetylcholine release from intramural cholinergic nerves (Gerner \& Haffner, 1977). But the hormonal action of circulating CCK has also been found to be mediated through specific receptors located on the smooth-muscle-cell membrane (Morgan et al. 1978). A central component cannot be excluded since intravenous administration of $\mathrm{CCK}_{8}$, which does not cross the blood-brain barrier (Zhu et al. 1986), has been found to activate hypothalamic neurons (Renaud et al. 1987) and to increase CCK concentrations in the lateral hypothalamus (McLaughlin et al. 1986).

Another peptide with a potent central action which disrupts the MMC pattern is corticotropin-releasing factor (CRF) but the effects of its icv administration are limited to the stomach (Bueno \& Fioramonti, 1986). This action which suppresses gastric MMC does not involve a peripheral release of corticotropin and cortisol. It is notable that acoustic stress in dogs induces the exact reproduction of the central effect of CRF on gastric motility (Gue et al. 1987). Since CRF is known to be released by stress (Rivier et al. 1982), this peptide may be responsible at the central level for the digestive motor disturbances observed in stressful conditions. This hypothesis is supported by observations in mice showing an acceleration of gastric emptying of nutritive meals by acoustic or cold stress being blocked by icv administration of an antiserum against CRF (Bueno \& Gue, 1988). 
The second group of hormones with a central action on digestive motility includes peptides which restore a MMC pattern on the jejunum when given by icv administration after a meal. Such an effect is not sufficient to demonstrate a central physiological action of these hormones, but it may indicate that the central nervous system is physiologically involved in the postprandial disruption of the intestinal MMC pattern. For example, MMC disruption can be blocked by icv administration of calcitonin, neurotensin (Bueno et al. $1983 b$ ) or growth-hormone-releasing factor (GRF) (Bueno et al. 1985b) at doses ineffective by the systemic route.

The mechanisms involved in the central action of these peptides are different. The central effect of calcitonin and neurotensin probably involves a release of prostaglandins since it is blocked by indomethacin (Bueno et al. 1985a), while that of GRF is mediated through dopaminergic receptors since it is blocked by metoclopramide (Bueno et al. 1985b). Moreover, the central digestive action of these peptides involves the same or different mechanisms which affect other physiological functions. For example, the central actions of calcitonin on both intestinal motility and feeding behaviour in rats are mediated through a release of prostaglandins (Fargeas et al. 1984). The effects on intestinal motility involve calcium fluxes, while those on body temperature are $\mathrm{Ca}$ independent (Fargeas et al. 1985).

The disruptive effects of centrally-administered CRF on gastro-duodenal MMC pattern in the fasted state, as well as the MMC restoring action of central calcitonin at the jejunoileal level in the fed state, are blocked by vagotomy (Bueno et al. 1985a; Gue et al. 1987). This is in agreement with the neural contribution during the inhibition of phase 3 activity by food which has been found to be mediated by extrinsic nerves (Ruckebusch \& Bueno, 1977 b; Diamant et al. 1980).

\section{NUTRITIONAL IMPLICATIONS}

Intestinal motility, digestive secretions and intestinal absorption are closely-related processes which control food digestion and nutrient absorption. Thus the action of food components influencing the release of GI hormones may be considered as a link between nutrition and digestive motility.

\section{HORMONAL INVOLVEMENT IN THE CONTROL OF DIGESTIVE MOTILITY BY FOOD}

In ruminants differences in the composition and amount of digesta passing into the abomasum induce secretion of variable amounts of hydrochloric acid and adaptation of the antro-duodenal motor profile. Both these gastric functions can be modulated by GI hormones. Bruce \& Huber (1973) have suggested that this hormonal regulation of GI motility could be extended to forestomach motility which determines the flow of digesta entering the abomasum. This hypothesis is supported by the fact that blood collected from a sheep given a duodenal infusion of lactic acid reduced forestomach motility when intravenously infused into another subject (Bruce \& Huber, 1973). It is feasible that this effect resulted from actions of secretin and CCK which are able to reduce the reticuloomasal flow of digesta, or gastrin which also inhibits reticulo-rumen contractions (Ruckebusch, 1971; Wilson et al. 1976).

In sheep and cattle spiking activity of the antrum is transiently inhibited, while omasal and duodenal activities are increased by pentagastrin. However, in sheep an intravenous injection of gastrin at a pharmacologically effective dose inhibited the flow of digesta through the omaso-abomasal orifice (Onapito et al. 1978). In the unweaned calf, a 
pentagastrin-induced inhibition of abomasal fundic and antral contractile activity led to a slow rate of abomasal emptying (Bell et al. 1977).

A meal of cereal pellets is able to disrupt the MMC pattern in sheep with an increase in the total electrical activity at both the antrum and small intestine (Bueno \& Fioramonti, 1980). This effect on gut motility may be secondary to the release of insulin; for example, the intravenous infusion of volatile fatty acids or insulin were found to disrupt the rhythms of abomaso-intestinal motility in normal sheep but not in diabetic sheep (Bueno \& Ruckebusch, 1976). The idea of a role for insulin has been re-inforced by an observation in the milk-fed lamb, that the postprandial disruption of the MMC is suppressed by alloxan-induced diabetes (Bueno \& Ruckebusch, 1976).

Furthermore intraduodenal infusion of lactic acid, which probably releases $\mathrm{CCK}_{8}$ (Bruce \& Huber, 1973), also inhibits the rate of ingestion. This effect was correlated with an alteration of forestomach motility (Duranton \& Bueno, 1983) and probably involved CCK and opiate receptors at the level of the central nervous system (Bueno et al. 1983a). These observations suggest that reduced food consumption observed with cereal pellets or molasses may result from a release of $\mathrm{CCK}_{8}$. In preruminant calves intravenous infusion of CCK has been found to inhibit antral motility, to reduce abomasal emptying and to stimulate gastric acid secretion (McLeay \& Bell, 1980).

In non-ruminants, the duration of the MMC disruption after a meal depends much more on the physico-chemical composition of the food than on its volume or its energy content. For example, ingestion of $125 \mathrm{~kJ} / \mathrm{kg}$ in the form of arachis oil in dogs disrupts the MMC pattern for $6 \mathrm{~h}$ while an isoenergetic meal of milk protein induces a MMC disruption for only $2 \mathrm{~h}$ (De Wever et al. 1978). However, such a MMC disruption by fats cannot be related to insulin or gastrin, their plasma concentration remaining unchanged after ingestion of $125 \mathrm{~kJ} / \mathrm{kg}$ in the form of arachis oil (Eeckhout et al. 1978). The digestive motor responses to fat in a meal may be mediated by CCK which is mainly released after ingestion of fat, at least in humans (Liddle et al. 1985), and which is considered to have a physiological action in the regulation of gastric emptying (Debas et al. 1975). However, a role for gastrin in the postprandial MMC disruption cannot be excluded since during total parenteral nutrition in dogs the MMC pattern persists in association with depressed concentrations of serum and antral gastrin (Weisbrodt et al. 1976).

Similarly, the fat component of the diet has been found to be the predominant stimulus of colonic motor activity in response to eating (Wright et al. 1980). However, CCK which also stimulates colonic motility cannot be considered as the major mediator of the colonic response to fat ingestion, stimulation of muscarinic receptors being required in the fat response but not in the CCK-induced colonic stimulation (Renny et al. 1983).

\section{CONSEQUENCES OF THE HORMONAL CONTROL OF DIGESTIVE MOTILITY ON NUTRIENT ABSORPTION}

In view of relationships between motility and other digestive functions, any hormone able to modify the pattern of GI contractions could have consequences for food utilization.

The first role attributed to the phase 3 activity of the MMC was that of a 'housekeeper' who cleans the small intestine of residual food, secretion and desquamated cells (Code \& Schlegel, 1974). The lack of phase 3 motor activity observed in patients with bacterial overgrowth of the small intestine (Vantrappen et al. (1977) implies that recurrent MMC may have a role in maintaining a stable microflora in the gut. However, it is unclear whether bacterial overgrowth was the cause or the consequence of the MMC disruption. More recently several pharmacologically-induced inhibitions of phase 3 activity in rats have been found associated with an increase in the number of micro-organisms in the small intestine (Scott \& Cahall, 1982). 
Raised values of gastric $\mathrm{pH}$ were observed during the phases of quiescence of gastric motility in dogs. This transitory decrease in acidity coincided with a duodeno-gastric reflux of intestinal contents (Bueno et al. 1981). Pancreatic and biliary flow are also associated with duodenal MMC. In dogs, maximal outputs of lipase ( $E C$ 3.1.1.3) and bilirubin appear during the duodenal propagation of phase 3 activity (Dimagno et al. 1979). Similarly bile acids, trypsin and bicarbonate outputs are maximal during phase 3 activity (Keane et al. 1980). However, the amount of pancreatic enzymes secreted during phase 3 activity was found to be $50 \%$ of that secreted during a similar time following ingestion of a meal.

Studies of absorption in animals prepared with isolated intestinal loops indicate that the rate of digesta passage affects the uptake of nutrients (Sarr et al. 1980). In experiments with intact animals the maximal absorption of glucose occurred during the later stages of phase 2 activity of the MMC, when the rate of transit was fastest compared with other phases of the intestinal motor complex (Fioramonti et al. 1982). These relationships between intestinal motility and absorption have been indirectly confirmed by the presence of the highest values of potential difference across the mucosa during phase 3 activity in dogs (Fioramonti \& Ruckebusch, 1978b) as well as in humans (Read, 1980). Moreover, mesenteric arterial blood flow, which controls passive paracellular absorption but also active transcellular transport through the oxygen supply, exhibits cyclic variations at the same frequency as recurrent MMC. Minimal blood flow occurs during the periods of intestinal motor quiescence (Fioramonti \& Bueno, 1984). However, maximal mesenteric blood flow has been observed after a meal (Vatner et al. 1970). Digestive hormones act on smooth muscles of both arteries and small intestine, but their effects can be similar or opposite. For example, gastrin and CCK increase and somatostatin decreases both blood flow and intestinal motility while glucagon inhibits motility and increases blood flow (Fondacaro, 1984).

\section{CONCLUSIONS}

The motility of the stomach and the small intestine is mainly characterized by MMC. Two hormones are probably involved in the control of their cyclic occurrence: motilin for the stomach and the duodenum, and somatostatin for the jejunum and the ileum. These two hormones exhibit plasma variations related to $\mathrm{MMC}$ occurrence and their intravenous administration is able to modify the MMC frequency. In non-ruminant species $\mathrm{MMC}$ is disrupted for several hours after a meal and the change from the fasted to the fed GI motor pattern is probably under the control of more than one hormone, including gastrin, insulin, and CCK. However, although hormones are undoubtedly involved in the disruption of the MMC, the role of each of these hormones is not clearly established. Moreover, there is now increasing evidence that the postprandial changes in the GI motor pattern involve the central nervous system. At this level evidence highlights a role for CCK, but its involvement as a hormone is uncertain.

No universal pattern of contractions characterizes colonic motility for which a hormonal control has been postulated in the hypermotility observed after a meal. However, information is lacking to establish a physiological role for hormones in the control of colonic motility.

Hormonal control of GI motility has two main nutritional implications. First the nature of food influences the postprandial motor pattern in part by its action on the release of GI hormone. Second GI motility is closely related to digestive secretions and nutrient absorption and a hormonal modification of intestinal motility implies consequences on other digestive functions. 


\section{REFERENCES}

Abrahamsson, H. (1973). Studies on the inhibitory nervous control of gastric motility. Acta Physiologica Scandinavica 390, Suppl., 1-38.

Aizawa, L., Itoh, A., Harris, V. \& Unger, R. (1981). Plasma somatostatin-like immunoreactivity during the interdigestive period in the dog. Journal of Clinical Investigations 68, 206-213.

Al Saffar, A. \& Rosell, S. (1981). Effects of neurotensin and neurotensin analogues on the migrating myoelectrical complexes in the small intestine of rats. Acta Physiologica Scandinavica 112, 203-208.

Ash, R. W. (1961). Stimuli influencing the secretion of acid by the abomasum of sheep. Journal of Physiology 157, 185-207.

Banta, C. A., Clemens, E. T., Krinsky, M. M. \& Sheffy, B. E. (1979). Sites of organic acid production and patterns of digesta movements in the gastrointestinal tract of dogs. Journal of Nutrition 109, 1592-1600.

Bell, F. R. \& Grivel, M. L. (1975). The effect of duodenal infusion on the electromyogram of gastric muscle during activation and inhibition of gastric emptying. Journal of Physiology 248, 377-391.

Bell, F. R., Titchen, D. A. \& Watson, D. J. (1977). The effect of the gastrin analogue, pentagastrin on the gastrin electromyogram and abomasal emptying in the calf. Research in Veterinary Science 23, 165-170.

Bormans, V., Peeters, T. L., Janssens, J., Pearce, D., Vandeweerd, M. \& Vantrappen, G. (1987). In man, only activity fronts that originate in the stomach correlate with motilin peaks. Scandinavian Journal of Gastroenterology 22, 78I-784.

Borody, T. J., Byrnes, D. J., Slowiaczek, J. G. \& Titchen, D. A. (1981). Motilin and migrating myoelectric complexes in pigs. Journal of Physiology 310, 37P-38P.

Brown, J. C., Cook, M. A. \& Dryburgh, J. R. (1972). Motilin, a gastric motor activity-stimulating polypeptide: final purification, amino acid composition, and C-terminal residues. Gastroenterology 61, 401-404.

Bruce, L. A. \& Hubert, T. L. (1973). Inhibitory effect of acid in the intestine on rumen motility in sheep. Journal of Animal Science 37, $164-168$.

Bueno, L. (1977). Complexe myoélectrique de l'intestin grêle et variations de l'apport alimentaire chez le mouton (Myoelectric complex of the small intestine and variations of food intake in the sheep). Comptes Rendus de la Société de Biologie 171, 959964.

Bueno, L., Duranton, A. \& Ruckebusch, Y. (1983a). Antagonistic effects of naloxone on CCK-octapeptide induced satiety and rumino-reticular motility in sheep. Life Sciences 32, 855-863.

Bueno, L., Fargeas, M. J., Fioramonti, J. \& Primi, M. P. (1985a). Central control of intestinal motility by prostaglandins: a mediator of the action of several peptides in rats and dogs. Gastroenterology 88, 1888-1894.

Bueno, L. \& Ferre, J. P. (1982). Central regulation of intestinal motility by somatostatin and cholecystokinin octapeptide. Science 216, 1427-1429.

Bueno, L., Ferre, J. P., Fioramonti, J. \& Honde, C. (1983 b). Effects of intracerebroventricular administration of neurotensin, substance $\mathbf{P}$ and calcitonin on gastrointestinal motility in normal and vagotomized rats. Regulatory Peptides 6, 197-205.

Bueno, L., Ferre, J. P., Fioramonti, J. \& Ruckebusch, M. (1982a). Control of the antral motor response to feeding by gastric acid secretion in rats. Journal of Physiology 325, 43-50.

Bueno, L. \& Fioramonti, J. (1980). Rhythms of abomaso-intestinal motility. In Digestive Physiology and Metabolism in Ruminants, pp. 53-80 [Y. Ruckebusch and P. Thivend, editors]. Lancaster: MTP Press Ltd.

Bueno, L. \& Fioramonti, J. (1986). Effects of corticotropin-releasing factor, corticotropin and cortisol on gastrointestinal motility in dogs. Peptides $7,73-77$.

Bueno, L., Fioramonti, J. \& Primi, M. P. (1985b). Central effects of growth hormone-releasing factor (GRF) on intestinal motility in dogs: involvement of dopaminergic receptors. Peptides 6, 403-407.

Bueno, L., Fioramonti, J., Rayner, V. \& Ruckebusch, Y. $(1982 b)$. Effects of motilin somatostatin and pancreatic polypeptide on the migrating myoelectric complex in pigs and dogs. Gastroenterology 44, 1395-1402.

Bueno, L., Fioramonti, J. \& Ruckebusch, Y. (1975). Rate of flow of digesta and electrical activity of the small intestine in dogs and sheep. Journal of Physiology 249, 69-85.

Bueno, L., Fioramonti, J. \& Ruckebusch, Y. (1981). Gastric pH changes associated with duodenal motility in fasted dogs. Journal of Physiology 316, 319-325.

Bueno, L. \& Gue, M. (1988). Evidence for the involvement of corticotropin-releasing factor in the gastrointestinal disturbances induced by acoustic and cold stress in mice. Brain Research 441, 1-4.

Bueno, L. \& Ruckebusch, M. (1976). Insulin release and jejunal electrical activity in dogs and sheep. American Journal of Physiology 230, 1538-1544.

Bueno, L. \& Ruckebusch, Y. (1974). The cyclic motility of the omasum and its control in sheep. Journal of Physiology 238, 295-312.

Bueno, L. \& Ruckebusch, Y. (1978). Migrating myoelectrical complexes. Disruption, enhancement and disorganisation. In Proceedings of the 6th International Symposium on Gastrointestinal Motility, Edinburgh, 1977, pp. 83-90 [H. L. Duthie, editor]. Lancaster: MTP Press Ltd.

Bueno, L., Weekes, T. E. C. \& Ruckebusch Y. (1977). Effects of diet on the motility of the small intestine and plasma insulin levels in sheep. Annales de Recherches Vétérinaires 8, 95-104. 
Burrows, C. F., Merritt, A. M. \& Tash, J. (1986). Jejunal myoelectrical activity in the conscious neonatal pig. Journal of Physiology 374, 349-357.

Chey, W. Y., Lee, K. Y. \& Tai, H. H. (1978). Endogenous plasma motilin concentration and interdigestive myoelectric activity of the canine duodenum. In Gut Hormones, pp. 355-358 [S. R. Bloom, editor]. Edinburgh: Churchill Livingstone.

Code, C. F. \& Marlett, J. A. (1975). The interdigestive myoelectric complex of the stomach and the small bowel of dogs. Journal of Physiology 246, 298-309.

Code, C. F. \& Schlegel, J. F. (1974). The gastrointestinal housekeeper. In Gastrointestinal Motility, pp. $631-633$. [E. E. Daniel, editor]. Vancouver: Mitchell Press.

Debas, H. T., Farooq, O. \& Grossman, M. I. (1975). Inhibition of gastric emptying is a physiological action of cholecystokinin. Gastroenterology 68, 1211-1217.

Defilippi, C. \& Valenzuela, J. E. (1981). Sham feeding disrupts the interdigestive motility complex in man. Scandinavian Journal of Gastroenterology 16, 977-979.

Deloof, S. \& Rousseau, J. P. (1985). Specific effects of thoracic vagotomy on the electrical activity of the gastric antrum and pylorus in rabbits. Quarterly Journal of Experimental Physiology 70, 491-501.

De Wever, I., Eeckhout, C., Vanrappen, G. \& Hellemans, J. (1978). Disruptive effect of test meals on interdigestive motor complex in dogs. American Journal of Physiology 235, E661-E665.

Diamant, N. E., Hall, K., Mui, H. \& El Sharkawy, T. Y. (1980). Vagal control of the feeding motor pattern in the lower oesophageal sphincter, stomach and small intestines of dog. In Gastrointestinal Motility, pp. 365-370. [J. Christensen, editor]. New York: Raven Press.

Dimagno, E. P., Hendricks, J. C., Go, V. L. W. \& Dozois, R. R. (1979). Relationships among canine fasting pancreatic and biliary secretions, pancreatic duct pressure, and duodenal phase III motor activity. Boldyreff revisited. Digestive Diseases and Sciences 24, 689-693.

Domschke, W., Strunz, V., Mitznegg, P., Domschke, S., Wunsch, E. \& Demling, L. (1976). Motilin and motilin analogues: mode of action. Scandinavian Journal of Gastroenterology 11 Suppl. 39, 25-28.

Duc, F. (1988). Contribution à l'étude du contrôle hormonal sur la motricité duodénale chez le rat. Rôle privilégié de la cholecystokinin. (Hormonal control of duodenal motility in the rat. Role of cholecystokinin.) Doctoral Thesis, University of Lyon.

Duranton, A. \& Bueno, L. (1983). A possible central opiate mechanism involved in the inhibition of food intake and reticular motility by duodenal DL-lactic acid infusion in sheep. American Journal of Veterinary Research 44, 802-805.

Eeckhout, C., De Wever, I., Peeters, I., Hellemans, J. \& Vantrappen, G. (1978). Role of gastrin and insulin in postprandial disruption of migrating complex in dog. American Journal of Physiology 235, E666-E669.

Ehrlein, H. J. (1970). Untersuchungen über die Motorik des Labmagens der Ziege unter besonderer Berücksichtigung des Pylorus. (Study of gastric and pyloric motility in the goat.) Zentralblatt für Veterinärmedizin 17, 481-497.

Fargeas, M. J., Fioramonti, J. \& Bueno, L. (1984). Prostaglandin $\mathrm{E}_{2}$ : a neuromodulator in the central control of gastrointestinal motility and feeding behavior by calcitonin. Science 225, 1050-1052.

Fargeas, M. J., Fioramonti, J. \& Bueno, L. (1985). Central actions of calcitonin on body temperature and intestinal motility in rats: evidence for different mediations. Regulatory Peptides 11, 95-103.

Ferris, C. F., George, J. K. \& Albers, H. E. (1986). Circadian thythm of neurotensin levels in rat small intestine. Regulatory Peptides 15, 285-292.

Fioramonti, J. (1981). Etude comparée des fonctions motrices du gros intestin. (A comparative study of large intestine motor functions.) Doctoral Thesis, University of Toulouse.

Fioramonti, J. \& Bueno, L. (1980). Motor activity in the large intestine of the pig related to dietary fibre and retention time. British Journal of Nutrition 43, 155-162.

Fioramonti, J. \& Bueno, L. (1983). Diurnal changes in colonic motor profile in conscious dogs. Digestive Diseases and Sciences 28, 257-264.

Fioramonti, J. \& Bueno, L. (1984). Relation between intestinal motility and mesenteric blood flow in the conscious dog. American Journal of Physiology 246, G108-G113.

Fioramonti, J., Bueno, L. \& Ruckebusch, Y. (1982). Blood sugars oscillations and duodenal migrating myoelectrical complexes. American Journal of Physiology 242, G15-G20.

Fioramonti, J., Garcia-Villar, R., Bueno, L. \& Ruckebusch, Y. (1980). Colonic myoelectrical activity and propulsion in the dog. Digestive Diseases and Sciences 25, 641-646.

Fioramonti, J. \& Hubert, M. F. (1980). Motor functions of the large intestine in sheep versus cattle. Annales de Recherches Vétérinaires 11, 109-115.

Fioramonti, J. \& Ruckebusch, Y. (1978a). On the control of caecal motility in sheep. Annales de Recherches Vétérinaires 9, 517-521.

Fioramonti, J. \& Ruckebusch, Y. (1978b). Potentiel transmural et profil moteur de l'intestin chez le chien. (Transmural potential difference and intestinal motor profile in the dog.) Comptes Rendus de la Société de Biologie 172, 186-190.

Fisher, R. \& Cohen, S. (1973). Physiological characteristics of the human pyloric sphincter. Gastroenterology 64, $67-75$.

Fondacaro, J. D. (1984). Intestinal blood flow and motility. In Physiology of the Intestinal Circulation, pp. 170-120. [A. P. Shepherd and D. N. Granger, editors]. New York: Raven Press. 
Fox, J. E. T., Track, N. S. \& Daniel, E. E. (1981). Relationship of plasma motilin concentration to fat ingestion, duodenal acidification and alkalinization, and migrating motor complexes in dogs. Canadian Journal of Physiology and Pharmacology 59, 180-187.

Frexinos, J., Bueno, L. \& Fioramonti, J. (1985). Diurnal changes in myoelectric spiking activity of the human colon. Gastroenterology 88, 1104-1110.

Gerner, T. \& Haffner, J.F.W. (1977). The role of local cholinergic pathways in the motor responses to cholecystokinin and gastrin in isolated guinea-pig fundus and antrum. Scandinavian Journal of Gastroenterology 12, $751-757$

Gill, R. C., Pilot, M. A., Thomas, P. A. \& Wingate, D. L. (1985). Organization of fasting and postprandial myoelectric activity in stomach and duodenum of conscious dogs. American Journal of Physiology 249, G655-G661.

Grossman, M. I. (1977). Physiological effects of gastrointestinal hormones. Federation Proceedings 36, 1930.

Gue, M., Fioramonti, J., Frexinos, J., Alvinerie \& M. Bueno, L. (1987). Influence of acoustic stress by noise on gastrointestinal motility in dogs. Digestive Diseases and Sciences 32, 1411-1471.

Hall, K. E., Greenberg, G. R., El-Sharkawy, T. Y. \& Diamant, N. E. (1983). Vagal control of migrating motor complex related peaks in canine plasma motilin, pancreatic polypeptide, and gastrin. Canadian Journal of Physiology and Pharmacology 61, 1289-1298.

Hall, K. E., Greenberg, G. R., El Sharkawy, T. Y. \& Diamant, N. E. (1984). Relationship between porcine motilin-induced migrating motor complex-like activity, vagal integrity and endogenous motilin release in dogs. Gastroenterology 87, 76-85.

Hecker, J. F. \& Grovum, W. L. (1975). Rates of passage of digesta and water absorption along the large intestines of sheep, cows and pigs. Australian Journal of Biological Sciences 28, 161-167.

Hinder, R. A. (1983). Individual and combined roles of the pylorus and the antrum in the canine gastric emptying of a liquid and a digestible solid. Gastroenterology 84, 281-286.

Hinder, R. A. \& Kelly, K. A. (1977). Human gastric pacesetter potential. Site of origin, spread, and response to gastric transection and proximal gastric vagotomy. American Journal of Surgery 133, 29-33.

Hostein, J., Janssens, J., Vantrappen, G., Peeters, T. L., Vandeweerd, M. \& Leman, G. (1984). Somatostatin induces ectopic activity fronts of the migrating motor complex via a local intestinal mechanism. Gastroenterology 87, 1004-1008.

Itoh, Z., Aizawa, I., Takeuchi, S. \& Couch, E. F. (1975). Hunger contractions and motilin. In Proceedings of the 5th International Symposium on G.I. Motilin, pp. 48-55. [G. Vantrappen, editor]. Typoff: Herentals.

Itoh, Z., Aizawa, I., Takeuchi, S. \& Takayanagi, R. (1977). Diurnal changes in gastric motor activity in conscious dogs. Digestive Diseases and Sciences 22, 117-124.

Itoh, Z., Takeuchi, S., Aizawa, I., Mori, K., Taminato, T., Seino, Y., Imura, H. \& Yanaihara, N. (1978). Changes in plasma motilin concentration and gastrointestinal contractile activity in the conscious dog. American Journal of Digestive Diseases 23, 929-935.

Jahnberg, T. (1977). Gastric adaptative relaxation. Scandinavian Journal of Gastroenterology 12, Suppl., 1-32.

Janssens, J., Hellemans, J., Adrian, T. E., Bloom, S. R., Peeters, T. L., Christofides, N. \& Vantrappen, G. R. (1982). Pancreatic polypeptide is not involved in the regulation of the migrating motor complex in man. Regulatory Peptides 3, $41-49$.

Janssens, J., Vantrappen, G. \& Peeters, T. L. (1983). The activity front of the migrating motor complex of the human stomach but not of the small intestine is motilin-dependent. Regulatory Peptides 6, 363-369.

Karmeli, R., Kamei, C., Schmalz, P., Yaksh T. \& Szurszewski, J. H. (1987). The effect of intracerebroventricular perfusion with CCK-OP on gastrointestinal myoelectric activity in the dog. Digestive Diseases and Sciences 32 , 916.

Kay, R. N. B. (1965). Movement of food through the abomasum. Wiener Tierärztliche Monatsschrift 5, 539-546.

Keane, F. B., DiMagno, E. P., Dozois, R. R. \& Go, V. L. W. (1980). Relationships among canine interdigestive exocrine pancreatic and biliary flow, duodenal motor activity, plasma pancreatic polypeptide and motilin. Gastroenterology 78, 310-316.

Kelly, K. A., Code, C. F. \& Elveback, L. R. (1969). Patterns of canine gastric electrical activity. American Journal of Physiology 217, 461-470.

Krejs, G. J., Orci, L., Conlon, J. M., Ravazzola, M., Davis, G. R., Raskin, P., Colin, S. M., McCarthy, D. M., Baetens, D., Rubenstein, A., Aldor, T. A. M. \& Unger, R. H. (1979). Somatostatinoma syndrome. Biochemical, morphological and clinical features. New England Journal of Medicine 301, 285-292.

Larsson, L. I. \& Rehfeld, J. R. (1979). Localization and molecular heterogeneity of cholecystokinin in the central and peripheral nervous system. Brain Research 165, 201-218.

Lee, K. Y., Chey, W. Y., Tai, H. H. \& Yajima, H. (1978). Radioimmunoassay of motilin: validation and studies on the relationship between plasma motilin and interdigestive myoelectric activity of the duodenum of dog. American Journal of Digestive Diseases 23, 789-795.

Lee, K. Y., Kim, M. S. \& Chey, W. Y. (1980). Effects of a meal and gut hormones on plasma motility and duodenal motility in dog. American Journal of Physiology 238, G280-G283.

Lewis, T. D., Collins, S. M., Fox, J. E. T., Daniel, E. E. \& Track, N. S. (1979). Initiation of migrating myoelectric complexes. Gastroenterology 77, 1217-1224.

Liddle, R. A., Goldfine, I. D., Rosen, M. S., Taplitz, R. A. \& Williams, J. A. (1985). Cholecystokinin bioactivity 
in human plasma: molecular forms, responses to feeding and relationship to gallbladder contraction. Journal of Clinical Investigation 75, $1144-1152$.

Lux, G., Femppel, J., Lederer, P., Rösch, W. \& Domschke, W. (1980). Somatostatin induces interdigestive intestinal motor and secretory complex-like activity in man. Gastroenterology 78, 1212.

McLaughlin, C. L., Baile, C. A. \& Della-Fera, M. A. (1986). Changes in brain CCK concentrations with peripheral CCK injections in Zucker rats. Physiology and Behavior 36, 477-482.

McLeay, L. M. \& Bell, F. R. (1980). Effect of cholecystokinin, secretin, glucagon and insulin on gastric emptying and acid secretion in the calf. American Journal of Veterinary Research 41, 1590-1594.

McLeay, L. M. \& Titchen, D. A. (1975). Gastric, antral and fundic pouch secretion in sheep. Journal of Physiology 248, $595-612$.

Marik, F. \& Code, C. F. (1975). Control of the interdigestive myoelectric activity in dogs by the vagus nerves and pentagastrin. Gastroenterology 69, 387-395.

Morgan, K. G., Schmalz, P. F., Go, V. L. W. \& Szurszewski, J. H. (1978). Electrical and mechanical effects of molecular variants of CCK on antral smooth muscle. American Journal of Physiology 235, E324-E239.

Mukhopadhyay, A. K., Thor, P. J., Copeland, E. M., Johnson, L. R. \& Weisbrodt, N. W. (1977). Effect of cholecystokinin on myoelectric activity of small bowel of the dog. American Journal of Physiology 232, E44-E47.

Nakaya, M., Takeuchi, S., Aizawa, I. \& Itoh, Z. (1981). Involvement of the central nervous system in regulation of interdigestive contractions in the stomach. Zeitschrift für Gastroenterologie 19, 435.

Onapito, S. J., Donawick, W. J. \& Merritt, A. M. (1978). Effects of gastrin on emptying and composition of digesta of the omasum of sheep. American Journal of Veterinary Research 39, 1456-1458.

Ormsbee, H. S., Telford, G. L. \& Mason, G. R. (1979). Required neural involvement in control of canine migrating motor complex. American Journal of Physiology 237, E451-E456.

Ormsbee, H. S., Koehler, S. L. \& Telford, G. L. (1978). Somatostatin inhibits motilin-induced interdigestive contractile activity in the dog. Digestive Diseases and Sciences 23, 781-788.

Owyang, C., Achem-Karam, S. R. \& Vinik, A. I. (1983). Pancreatic polypeptide and intestinal migrating motor complex in humans. Effect of pancreaticobiliary secretion. Gastroenterology 84, 10-17.

Pascaud, X., Ferre, J. P., Genton, M., Roger, A., Ruckebusch, Y. \& Bueno, L. (1982). Intestinal motility response to insulin and glucagon in streptozotocin diabetic rats. Canadian Journal of Physiology and Pharmacology 60, 960967.

Peeters, T. L., Janssens, J. \& Vantrappen, G. R. (1983). Somatostatin and the interdigestive migrating motor complex in man. Regulatory Peptides 5, 209-217.

Peeters, T. L., Vantrappen, G. \& Janssens, J. (1980). Fasting plasma motilin levels are related to the interdigestive motility complex. Gastroenterology 79, 716-719.

Peeters, T. L., Vantrappen, G. \& Janssens, J. (1982). In Control of Gut Motility in Systemic Role of Regulatory Peptides, pp. 195-207. [S. R. Bloom and J. M. Polak, editors]. Stuttgart: Schattauer Verlag.

Plonait, H. (1974). Measurement of stomach motility using surgically implanted telemetry transmitters. Proceedings of the 3rd International Congress of the Pig Veterinary Society, Lyon, p. L10 (3-6).

Poitras, P., Steinbach, J. H. \& Van Devenier, G. (1980). Motilin-independent ectopic fronts of the interdigestive myoelectric complex in dogs. American Journal of Physiology 239, G125-G220.

Quigley, J. P. \& Louckes, H. S. (1962). Gastric emptying. American Journal of Digestive Diseases 7, 672-676.

Rayner, V., Christofides, N. D., Gregory, P., Goodall, E. D. \& Bloom, S. R. (1987). Motilin secretion and the migrating myoelectric complex in the pig. Quarterly Journal of Experimental Physiology 72, 51-60.

Rayner, V., Weekes, T. E. C. \& Bruce, J. B. (1981). Insulin and myoelectric activity of the small intestine of the pig. Digestive Diseases and Sciences 26, 33-41.

Rayner, V. \& Wenham, $G(1986)$. Small intestinal motility and transit by electromyography and radiology in the fasted and fed pig. Journal of Physiology 379, 245-256.

Read, N.W. (1980). The migrating motor complex and spontaneous fluctuations of transmural potential difference in the human small intestine. In Gastrointestinal Motility, pp. 299-306. [J. Christensen editor]. New York: Raven Press.

Rees, W. D. W., Malagelada, J. R., Miller, L. J. \& Go, V. L. W. (1982). Human interdigestive and postprandial gastrointestinal motor and gastrointestinal hormone patterns. Digestive Diseases and Sciences 527, 321-329.

Renaud, L. P., Tang, M., McCann, M. J., Stricker, E. M. \& Verbalis, J. G. (1987). Cholecystokinin and gastric distension activate oxytocinergic cells in rat hypothalamus. American Journal of Physiology 253. R661-R665.

Renny, A., Snape, W. J., Sun, E. A., London, R. \& Cohen, S. (1983). Role of cholecystokinin in the gastrocolonic response to a fat meal. Gastroenterology 85, 17-21.

Rivier, C., Rivier, J. \& Vale, W. (1982). Inhibition of adrenocorticotropic hormone secretion in the rat by immunoneutralisation of corticotropin releasing factor. Science $\mathbf{2 1 8}, 377-378$.

Roche, M., Bueno, L., Vagne, M. \& Blourde, C. (1982). Patterns of electrical activity in the digestive tract of conscious cats. British Journal of Nutrition 48, 129-135.

Ruckebusch, M. \& Ferre, J. P. (1973). Origine alimentaire des variations nycthémérales de l'activité électrique de l'intestin grêle chez le rat. (Alimentary origin of the nycthemeral variations of intestinal activity in the rat.) Comptes Rendus de la Société de Biologie 167, 2005-2009.

Ruckebusch, M. \& Fioramonti, J. (1975). Electrical spiking activity and propulsion in small intestine in fed and fasted rats. Gastroenterology 68, 1500-1508. 
Ruckebusch, Y. (1970). The electrical activity of the digestive tract of the sheep as an indication of the mechanical events in various regions. Journal of Physiology 210, 857-882.

Ruckebusch, Y. (1971). The effect of pentagastrin on the motility of ruminant stomach. Experientia 27, 1185-1186.

Ruckebusch, Y. \& Bueno, L. (1973). The effect of weaning on the motility of the small intestine in the calf. British Journal of Nutrition 30, 491-499.

Ruckebusch, Y. \& Bueno, L. (1976). The effect of feeding on the motility of the stomach and small intestine in the pig. British Journal of Nutrition 35, 397-405.

Ruckebusch, Y.\& Bueno, L. (1977a). Origin of migrating myoelectric complex in sheep. American Journal of Physiology 233, E483-E487.

Ruckebusch, Y. \& Bueno, L. (1977b). Migrating myoelectrical complex of the small intestine. An intrinsic activity mediated by the vagus. Gastroenterology 73, $1309-1314$.

Sarna, S., Chey, W. Y., Condon, R. E., Dodds, W. J., Myers, T. \& Chang, T. (1983). Cause-and-effect relationship between motilin and migrating myoelectric complexes. American Journal of Physiology 245, G277-G284.

Sarr, M. G. \& Kelly, K. A. (1981). Myoelectric activity of the autotransplanted canine jejuno ileum. Gastroenterology 81, 303-310.

Sarr, M. G., Kelly, K. A. \& Phillips, S. F. (1980). Canine jejunal absorption and transit during interdigestive and digestive motor states. American Journal of Physiology 239, G167-G172.

Schick, R. F., Reilly, W. M., Roddy, D. R., Yaksh, T. L. \& Go, V. L. W. (1987). Neuronal cholecystokinin-like immunoreactivity is postprandially released from primate hypothalamus. Brain Research 418, $20-26$.

Schippers, E., Janssens, J., Vantrappen, G., Vandeweerd, M. \& Peeters, T. L. (1986). Somatostatin induces ectopic activity fronts via a local intestinal mechanism during fed state or pentagastrin. American Journal of Physiology 250, G149-G154.

Schwartz, T. W., Stanquist, B., Olbe, L. \& Stadil, F. (1979). Synchronous oscillations in the basal secretion of pancreatic polypeptide and gastric acid. Gastroenterology 76, $14-19$.

Scott, L. D. \& Cahall, D. L. (1982). Influence of the interdigestive myoelectric complex on enteric flora in the rat. Gastroenterology 82, 737-745.

Shaw, C. \& Buchanan, K. D. (1983). Intact neurotensin (NT) in human plasma: response to oral feeding. Regulatory Peptides 7, 145-153.

Sissons, J. W. (1983). Effect of feed intake on digesta flow and myoelectric activity in the gastrointestinal tract of the preruminant calf. Journal of Dairy Research 50, 387-395.

Smith, J. R., Lahann, T. R., Chesnut, R. M., Carion, M. A. \& Horita, A. (1977). Thyrotropin releasing hormone: stimulation of colonic activity following intracerebroventricular administration. Science 196, $660-662$.

Snape, W. J., Matarazzo, A. \& Cohen, S. (1978). Effect of eating and gastrointestinal hormones on human colonic myoelectrical and motor activity. Gastroenterology 75, 373-378.

Snape, W. J., Wright, S. H., Battle, W. M. \& Cohen, S. (1979). The gastrocolic response: evidence for a neural mechanism. Gastroenterology 77, 1235-1340.

Summers, R. W., Flatt, A., Yanda, R. J. \& Yamada, T. (1984). Isoproterenol induces activity fronts in fed dogs through somatostatin release. Gastroenterology $87,999-1003$.

Svendsen, P. (1969). Etiology and pathogenesis of abomasal displacement in cattle. Nordisk Veterinärmedicin 21 Suppl. 1, 1-40.

Szurszewski, J. H. (1969). A migrating electric complex of the canine small intestine. American Journal of Physiology 217, 1757-1763.

Thomas, P. A. \& Kelly, K. A. (1979). Hormonal control of interdigestive motor cycles of canine proximal stomach. American Journal of Physiology 237, E192-E197.

Thomas, P. A., Kelly, K. A. \& Go, V. L. W. (1979) Does motilin regulate canine interdigestive gastric motility? Digestive Diseases and Sciences 24, 577-582.

Thor, K. \& Rosell, S. (1986). Neurotensin increases colonic motility. Gastroenterology 90, 27-31.

Thor, K., Rosell, S., Rokaeus, A. \& Kager, L. (1982). (Gln ${ }^{4}$-neurotensin changes the motility pattern of the duodenum and proximal jejunum from a fasting-type to a fed-type. Gastroenterology 83, 569-574.

Vantrappen, G., Janssens, J., Hellemans, J. \& Ghoos, Y. (1977). The interdigestive motor complex of normal subjects and patients with bacterial overgrowth of the small intestine. Journal of Clinical Investigation 59 , $1158-1166$.

Vantrappen, G., Janssens, J., Peeters, T. L., Bloom, S. R., Christofides, N. D. \& Hellemans, J. (1979). Motilin and the interdigestive migrating motor complex in man. Digestive Diseases and Sciences 24, 497-500.

Vatner, S. F., Franklin, D. \& Van Citters, R. L. (1970). Mesenteric vasoactivity associated with eating and digestion in the conscious dog. American Journal of Physiology 219, 170-174.

Weisbrodt, N. W., Copeland, E. M., Kearley, R. W., Moore, E. P. \& Johnson, L. C. (1974). Effects of pentagastrin on electrical activity of small intestine of the dog. American Journal of Physiology 277, 425-429.

Weisbrodt, N. W., Copeland, E. M., Thor, P. J. \& Dudrick, S. J. (1976). The myoelectric activity of the small intestine of the dog during total parenteral nutrition. Proceedings of the Society for Experimental Biology and Medicine 153, 121-124.

Wenham, G. (1974). X-ray image intensification in ruminant physiology. Proceedings of the Nutrition Society 33, 135-139. 
Wilson, R. C., Goetsch, D. D. \& Huber, T. L. (1976). Studies of mechanisms of action of secretin and pancreozymin on rumen motility. American Journal of Veterinary Research 37, 1131-1134.

Wingate, D. L., Pearce, E. A., Hutton, M., Dand, A., Thompson, H. H. \& Wunsche, E. (1978a). Quantitative comparison of the effects of cholecystokinin, secretin and pentagastrin on gastrointestinal myoelectric activity in the conscious fasted dog. Gut 19, 593-601.

Wingate, D. L., Pearce, E. A., Thomas, P. A. \& Boucher, B. J. (1987b). Glucagon stimulates intestinal myoelectric activity. Gastroenterology 74, 1152.

Wingate, D. L., Ruppin, H., Green, W. E. R., Thompson, H. H., Domschke, W., Wunsch, E., Demling, L. \& Ritchie, D. (1976). Motilin-induced electrical activity in the canine gastrointestinal tract. Scandinavian Journal of Gastroenterology 11 Suppl. 39, 111-118.

Wright, S. H., Snape, W. J., Battle, W., Cohen, S. \& London, R. L. (1980). Effect of dietary components on gastrocolonic response. American Journal of Physiology 238 G228-G232.

Yanda, R. \& Summers, R. W. (1983). Activity fronts in fed dogs: effect of a $\beta$-adrenergic agonist. American Journal of Physiology 245, G647-G650.

You, C. H., Chey, W. Y. \& Lee, K. Y. (1980). Studies on plasma motilin concentration and interdigestive motility of the duodenum in humans. Gastroenterology 79, 62-66.

Zhu, X. G., Greeley, G. H., Lewis, B. G., Lilja, P. \& Thompson, J. C. (1986). Blood-CSF barrier to CCK and effect of centrally administered bombesin on release of brain CCK. Journal of Neuroscience Research 15 , $393-403$. 